\title{
Pacjent z niewydolnością serca w okresie vulnerable phase
}

\author{
Patient with heart failure in vulnerable phase \\ Katarzyna Matyjas, Małgorzata Lelonek \\ Zakład Kardiologii Nieinwazyjnej Uniwersytetu Medycznego w Łodzi
}

\section{Streszczenie}

Pomimo rozwoju kardiologii niewydolność serca (HF) nadal pozostaje poważnym problem klinicznym. Każda hospitalizacja z powodu HF pogarsza rokowanie i zwiększa ryzyko zgonu pacjenta. Zapobieganie hospitalizacjom z powodu HF jest jednym z najważniejszych celów terapeutycznych w opiece nad pacjentami z HF. Wśród chorych z ostrą manifestacją HF najistotniejszym okresem dla dalszego przebiegu choroby jest faza tak zwanej największej wrażliwości (vulnerable phase). Jest to czas od wystąpienia objawów ostrej HF do 6 miesięcy po wypisie ze szpitala. Vulnerable phase składa się z trzech okresów: very early phase, early phase oraz late phase. Identyfikacja celów terapeutycznych w każdym z nich jest istotna dla osiągnięcia długoterminowej stabilizacji stanu klinicznego. Optymalne leczenie farmakologiczne i kompleksowa, multidyscyplinarna opieka na każdym z wyżej wymienionych etapów powoduje zmniejszenie częstości ponownych hospitalizacji oraz poprawę rokowania u pacjentów z HF.

Słowa kluczowe: niewydolność serca, vulnerable phase

Folia Cardiologica 2018; 13, 1: 71-78

\section{Wstęp}

Niewydolność serca (HF, heart failure) stanowi istotny problem zarówno zdrowotny, społeczny, jak i ekonomiczny. Szacuje się, że dotyczy 1-2\% społeczeństwa krajów rozwiniętych, a w grupie wiekowej powyżej 70. roku życia choruje co 10. osoba [1]. W Polsce, jak się szacuje, jest to 600-700 tys. pacjentów [2, 3].

W ciągu ostatnich 30 lat dokonał się ogromny postęp w leczeniu niewydolności serca. Wprowadzono do leczenia inhibitory konwertazy angiotensyny, beta-adrenolityki, antagonistów receptora mineralokortykoidowego, iwabradynę oraz antagonistów receptorów angiotensyny II i inhibitory neprylizyny (ARNI, angiotensin-receptor neprilysin inhibitors), nastąpił rozwój metod rewaskularyzacji, leczenia wad serca oraz elektroterapii. Mimo tego przewiduje się ciągły wzrost chorobowości i liczby hospitalizacji pacjentów z HF w starzejącym się społeczeństwie [4].
Według narodowego programu wyrównywania dostępności do profilaktyki i leczenia chorób układu sercowo-naczyniowego POLKARD, diagnostyka i leczenie pacjentów z HF pochłania 3,2\% środków finansowych Narodowego Funduszu Zdrowia (NFZ) [5]. Najbardziej kosztowną częścią opieki nad chorym z HF są powtarzające się hospitalizacje z powodu zaostrzeń choroby [6]. Według Amerykańskiego Towarzystwa Kardiologicznego (AHA, American Heart Association) 25\% pacjentów jest ponownie przyjmowanych do szpitala w ciągu pierwszych 30 dni od wypisu, najczęściej z powodu ponownej dekompensacji HF. Ryzyko zgonu lub ponownej hospitalizacji w pierwszych 90 dniach od wypisu stanowi aż 35-40\% (ryc. 1) [7, 8]. Każda kolejna hospitalizacja z powodu HF znacząco pogarsza rokowanie i zwiększa ryzyko zgonu pacjenta. Dlatego zapobieganie hospitalizacjom z powodu HF jest jednym z najważniejszych celów terapeutycznych w opiece nad pacjentami z HF $[6,9,10]$. 


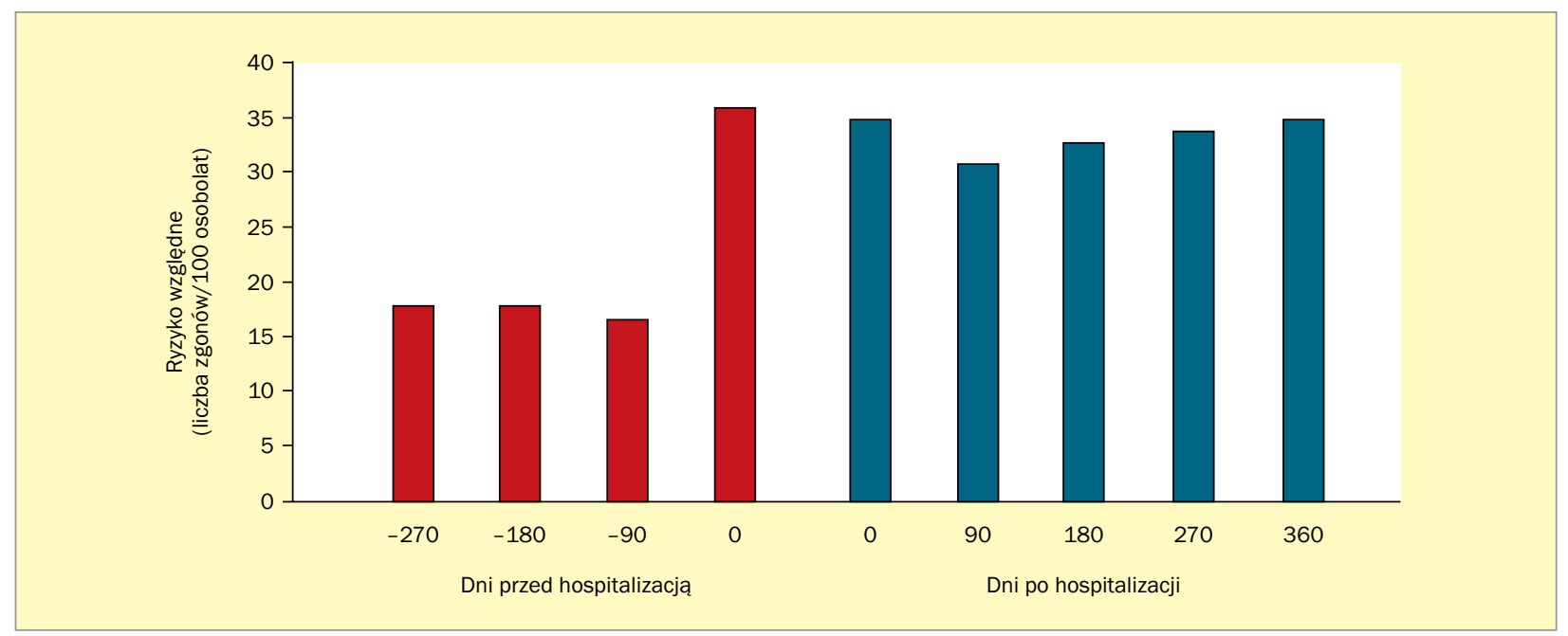

Rycina 1. Ryzyko zgonu przed i po hospitalizacji z powodu niewydolności serca (HF, heart failure) (na podstawie $[7,8]$ )

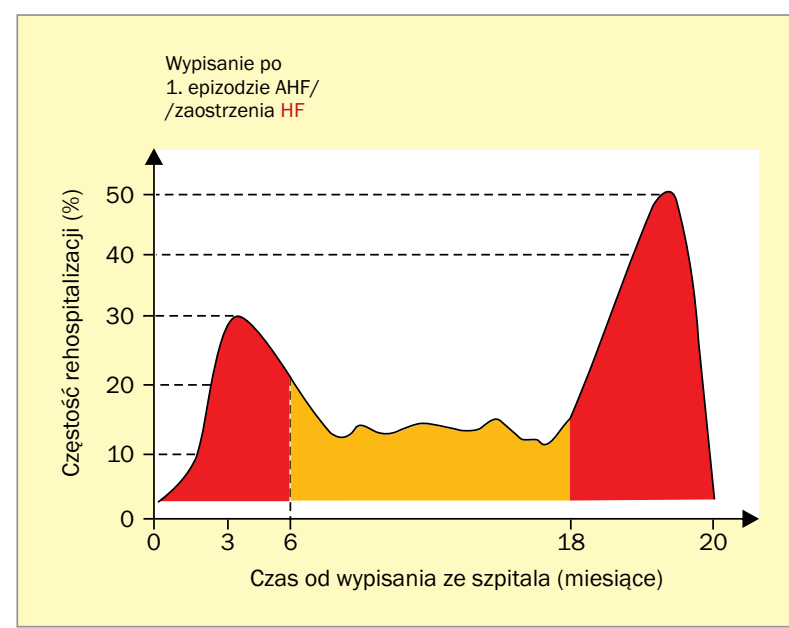

Rycina 2. Ryzyko readmisji po hospitalizacji z powodu niewydolności serca (HF, heart failure) (na podstawie [11]); AHF (acute heart failure) - ostra niewydolność serca
Dla pacjenta z ostrą HF de novo lub z dekompensacją przewlekłej HF najistotniejszym okresem dla przebiegu choroby jest faza największej wrażliwości (vulnerable phase). Jest to czas od momentu wystąpienia objawów ostrej $\mathrm{HF}$, przez cały okres hospitalizacji oraz okres okołowypisowy, do 6 miesięcy od wypisu ze szpitala. Ryzyko ponownej hospitalizacji a także zgonu jest wówczas szczególnie wysokie (ryc. 2 [11]) [12, 13].

Faza największej wrażliwości składa się z trzech okresów: okresu bardzo wczesnego (very early phase), okresu wczesnego (early phase) oraz okresu późnego (late phase). Występują one po sobie i mogą się częściowo nakładać. Etapy składające się na fazę największej wrażliwości pacjenta z HF przedstawiono na rycinie 3 [13]. Identyfikacja celów terapeutycznych w każdym z nich jest niezwykle istotna dla osiągnięcia długoterminowej stabilizacji stanu klinicznego. Optymalne leczenie farmakologiczne i kompleksowa, multidyscyplinarna opieka na każdym z wyżej

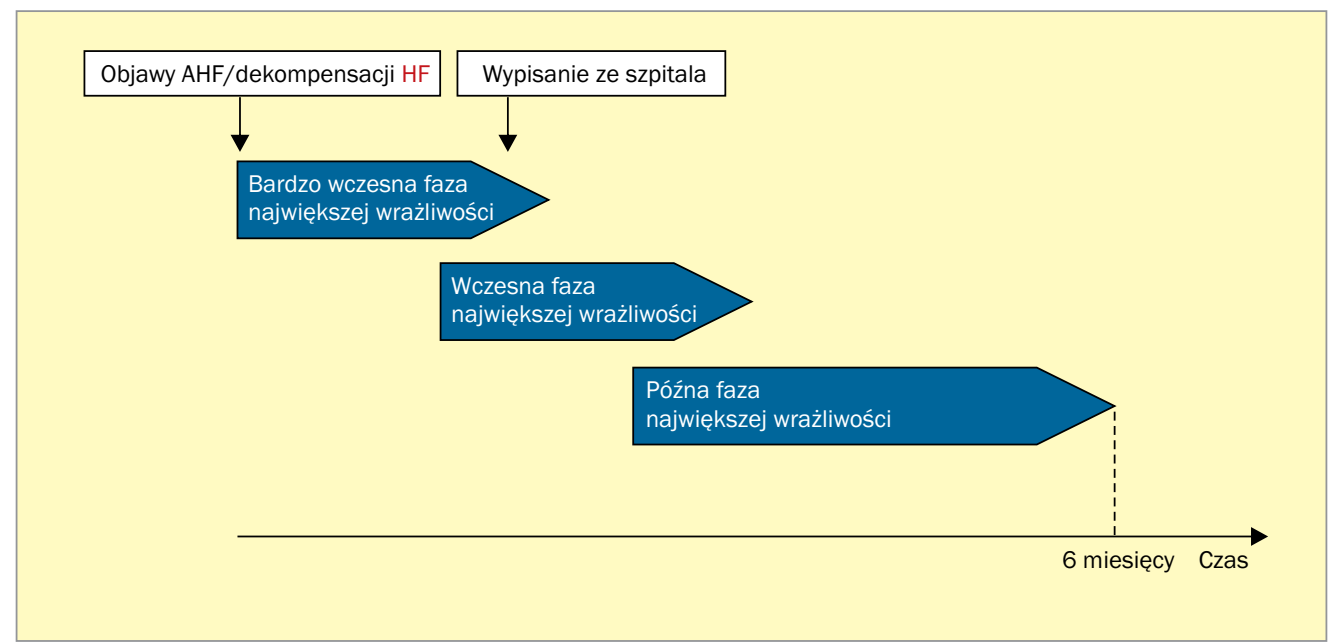

Rycina 3. Etapy składające się na fazę największej wrażliwości (na podstawie [13]); AHF (acute heart failure) - ostra niewydolność serca 
Tabela 1. Okres największej wrażliwości u pacjentów z niewydolnością serca

\begin{tabular}{|c|c|c|}
\hline $\begin{array}{l}\text { Okresy najwięk- } \\
\text { szej wrażliwości }\end{array}$ & Okres trwania & Cele terapeutyczne \\
\hline Bardzo wczesny & $\begin{array}{l}\text { Od momentu wystąpienia } \\
\text { ostrego epizodu AHF lub } \\
\text { dekompensacji przewlekłej } \\
\text { HF do kilku dni po wypisie } \\
\text { ze szpitala }\end{array}$ & $\begin{array}{l}\text { Stabilizacja stanu hemodynamicznego } \\
\text { Eliminacja niedotlenienia oraz hipoperfuzji narządowej } \\
\text { Wyrównanie wolemii (włączenie diuretyków w odpowiedniej dawce) } \\
\text { Zapobieganie uszkodzeniom narządowym } \\
\text { Obniżenie ryzyka wczesnych powikłań } \\
\text { Skracanie pobytu na oddziale intensywnej terapii } \\
\text { Włączenie inhibitora ACE oraz beta-adrenolityka w przypadku braku przeciwwskazań } \\
\text { Zaplanowanie opieki nad pacjentem po wypisaniu ze szpitala }\end{array}$ \\
\hline Wczesny & $\begin{array}{l}\text { Od wypisania ze szpitala po } \\
\text { osiągnięciu stabilizacji sta- } \\
\text { nu klinicznego i euwolemii }\end{array}$ & $\begin{array}{l}\text { Optymalizacja farmakoterapii ze szczególnym uwzględnieniem kontroli HR } \\
\text { za pomocą beta-adrenolityku oraz ew. iwabradyny } \\
\text { Kontrolna wizyta lekarska w gabinecie lekarza POZ w ciągu } 7 \text { dni od wypisania, } \\
\text { a jeśli to możliwe - kontrola u kardiologa, najlepiej z zespołu szpitalnego } \\
\text { w ciągu } 2 \text { tygodni od wypisania } \\
\text { Intensywne leczenie chorób towarzyszących }\end{array}$ \\
\hline Późny & Do 6 miesięcy po wypisie & $\begin{array}{l}\text { Obserwacja w kierunku pierwszych objawów rozpoczynającego się zastoju } \\
\text { Dalsza optymalizacja farmakoterapii } \\
\text { Rozważenie wskazań do elektroterapii (po } 3 \text { mies. optymalnego leczenia) } \\
\text { Kontynuacja wielodyscyplinarnej opieki nad pacjentem, z udziałem m.in. lekarza, } \\
\text { pielęgniarki, dietetyka, psychologa } \\
\text { Intensywna edukacja pacjenta i jego rodziny }\end{array}$ \\
\hline
\end{tabular}

wymienionych etapów powoduje zmniejszenie częstości ponownych hospitalizacji oraz poprawę rokowania u pacjentów z HF [14].

\section{Charakterystyka i cele terapeutyczne poszczególnych faz}

Okres trwania i najważniejsze cele poszczególnych okresów fazy największej wrażliwości przedstawiono w tabeli 1.

\section{Okres bardzo wczesny}

Jest to okres między wystąpieniem objawów ostrej HF de novo lub zaostrzenia przewlekłej HF, do kilku dni po wypisie ze szpitala. Głównym celem terapeutycznym w tej fazie jest uzyskanie stabilnego stanu hemodynamicznego, eliminacja objawów oraz zapobieganie uszkodzeniom narządowym. Realizacja wyżej wymienionych celów ogranicza ryzyko ponownych hospitalizacji z powodu kolejnych zaostrzeń HF [1]. U około 15\% pacjentów hospitalizowanych z powodu zaostrzenia HF, po osiągnięciu wstępnej stabilizacji stanu klinicznego, dochodzi do ponownego pojawienia się objawów, wymagającego intensyfikacji leczenia (worsening-HF). Jest to czynnik prognostyczny, związany z niekorzystnym rokowaniem w tej grupie chorych $[15,16]$.

Znaczenie działań mających na celu zapobieganie uszkodzeniom narządowym w przebiegu ostrej HF zosta- ło podkreślone w ostatnio opublikowanym stanowisku ekspertów European Society of Cardiology (ESC). Najważniejszą rolę w patofizjologii uszkodzeń narządowych pełni zastój, którego objawy dominują w obrazie klinicznym tej grupy pacjentów. Rzadziej są to cechy hipoperfuzji narządowej oraz wstrząsu kardiogennego. Uszkodzenie prowadzące do niewydolności narządów (serca, mózgu, nerek, wątroby, płuc, jelit) jest związane z gorszym rokowaniem i wzrostem śmiertelności u pacjentów z ostrą HF. Profilaktyka i leczenie uszkodzeń narządowych powinno być priorytetem w bardzo wczesnej fazie [17].

Pacjent może zostać wypisany ze szpitala po $24-48 \mathrm{~h}$ od osiągnięcia stabilnego stanu klinicznego, bez cech zastoju, po ustaleniu leczenia doustnego, ze stabilnymi parametrami funkcji nerek oraz wątroby, a także po wyrównaniu stężeń elektrolitów w surowicy. Średni okres hospitalizacji pacjentów z HF w 2012 roku w Polsce wynosił 6 dni (mediana) [6]. W wielu przypadkach jest to zbyt krótki czas, aby osiągnąć wyżej wymienione cele. Powszechnie występująca tendencja do skracania czasu trwania hospitalizacji (głównie ze względu na ograniczanie kosztów) generuje stosowanie dużych dawek diuretyków, tak aby uzyskać ustąpienie cech zastoju w możliwie najkrótszym czasie. Taka strategia może prowadzić do uszkodzenia nerek, dyselektrolitemii oraz niedotlenienia tkanek, co pogarsza rokowanie pacjentów z HF [18]. Proces ustalania 
odpowiednich dawek leków doustnych, dostosowywanych indywidualnie do sytuacji klinicznej, pod kontrolą między innymi ciśnienia tętniczego, częstości rytmu serca, parametrów nerkowych nie może być zrealizowany w zbyt krótkim czasie.

Do zadań w bardzo wczesnej fazie należy także zaplanowanie długoterminowej opieki nad pacjentem po wypisie ze szpitala [19].

\section{Okres wczesny}

Kluczową rolę w okresie wczesnym odgrywa opieka ambulatoryjna. Kontynuacja wielodyscyplinarnego planu opieki umożliwia prewencję ponownych hospitalizacji, pojawienia się objawów zaostrzenia HF oraz poprawia jakość życia pacjentów z HF. Ambulatoryjna optymalizacja leczenia przez lekarza podstawowej opieki zdrowotnej (POZ) oraz kardiologa w poradni specjalistycznej to jeden z najważniejszych celów terapeutycznych fazy wczesnej [20].

Jedną z podstawowych grup leków stosowanych w leczeniu HF są inhibitory ACE (angiotensin-converting enzyme) - zalecane u wszystkich pacjentów z niewydolnością serca w II-IV klasie według NYHA (New York Heart Assotiation) oraz frakcją wyrzutową lewej komory (LVEF left ventricular ejection fraction) nie większą niż $40 \%$. Stosowanie tej grupy leków prowadzi do zmniejszenia ryzyka przedwczesnego zgonu i hospitalizacji z powodu HF [1]. Inhibitory konwertazy angiotensyny należy włączyć do leczenia jak najszybciej w fazie bardzo wczesnej i co 2-4 tygodnie zwiększać dawkę do docelowej lub maksymalnie tolerowanej przez pacjenta. Początkowe i docelowe dawki inhibitorów ACE przedstawiono w tabeli 2.

Kolejnym istotnym czynnikiem rokowniczym stanowiącym cel terapeutyczny jest częstość rytmu serca. Efekt chronotropowo ujemny jest uzyskiwany poprzez włączenie do leczenia beta-adrenolityku i stopniowe zwiększanie dawki, aż do osiągnięcia dawki zalecanej (tab. 3). Ze względu na występujące objawy uboczne i/lub niepożądane tej grupy leków, dawkę docelową osiąga się tylko u części pacjentów. Hipotonia, bradykardia czy nasilenie objawów bronchospastycznych powodowały, że u blisko 80\% pacjentów nie osiągano dawki zalecanej, co pokazało badanie ZOPAN [21]. Jak wskazują wyniki rejestru OPTIMIZE, u 2/3 chorych nie zmieniano dawki beta-adrenolityków w ciągu 60-90 dni od zakończenia hospitalizacji [22]. Ponadto u $70 \%$ pacjentów wypisywanych ze szpitala odnotowano HR większe lub równe 70/min [23].

U pacjentów z EF nieprzekraczającą 35\% i wykazujących objawy niewydolności w II-IV klasie według NYHA poddanym standardowej terapii HF z utrzymującym się HR większym lub równym 70/min, mimo stosowania maksymalnej tolerowanej dawki beta-adrenolityku, lub pacjentów, którzy nie tolerują beta-adrenolityków, należy włączyć iwabradynę. W badaniu SHIFT, w którym populację stanowili pacjenci w II-IV okresie hemodynamicznym według NYHA, z LVEF
Tabela 2. Początkowe i docelowe dawki inhibitora konwertazy angiotensyny (na podstawie [1])

\begin{tabular}{lcc} 
Lek & \multicolumn{2}{c}{ Dawka } \\
& Początkowa & Docelowa \\
Kaptopril & $3 \times 6,25 \mathrm{mg} / \mathrm{d}$. & $3 \times 50 \mathrm{mg} / \mathrm{d}$. \\
Enalapril & $2 \times 2,5 \mathrm{mg} / \mathrm{d}$. & $2 \times 10-20 \mathrm{mg} / \mathrm{d}$. \\
Lisinopril & $1 \times 2,5-5 \mathrm{mg} / \mathrm{d}$. & $1 \times 20-35 \mathrm{mg} / \mathrm{d}$. \\
Ramipril & $1 \times 2,5 \mathrm{mg} / \mathrm{d}$. & $2 \times 5 \mathrm{mg} / \mathrm{d}$. \\
Trandolapril & $1 \times 0,5 \mathrm{mg} / \mathrm{d}$. & $1 \times 4 \mathrm{mg} / \mathrm{d}$.
\end{tabular}

Tabela 3. Dawki początkowe oraz docelowe leków beta-adrenolitycznych w niewydolności serca (na podstawie [1])

\begin{tabular}{lcc} 
Lek & \multicolumn{2}{c}{ Dawka } \\
& Początkowa & Docelowa \\
\hline $\begin{array}{l}\text { Bisoprolol } \\
\text { Karwedilol }\end{array}$ & $1 \times 1,25 \mathrm{mg} / \mathrm{d}$. & $1 \times 10 \mathrm{mg} / \mathrm{d}$. \\
$\begin{array}{l}\text { Bursztynian } \\
\text { metoprololu }\end{array}$ & $1 \times 12,5-25 \mathrm{mg} / \mathrm{d}$. & $1 \times 200 \mathrm{mg} / \mathrm{d}$. \\
Nebiwolol & $1 \times 1,25 \mathrm{mg} / \mathrm{d}$. & $1 \times 10 \mathrm{mg} / \mathrm{d}$.
\end{tabular}

poniżej 35\%, z rytmem zatokowym ponad 70/min, hospitalizowani w ciągu ostatnich 12 miesięcy, udowodniono, że dołączenie iwabradyny do standardowego leczenia HF powoduje zmniejszenie względnego ryzyka zgonu oraz ponownej hospitalizacji o 18\% [24]. Hidalgo i wsp. [25] w badaniu ETHIC-AHF udowodnili, że intensyfikacja leczenia ma szczególne znaczenie w okresie największej wrażliwości po hospitalizacji - w ciągu pierwszych 30-60 dni. Jednoczesne podawanie beta-adrenolityku i iwabradyny chorym ustabilizowanym po dekompensacji powoduje istotne zwolnienie HR po 28 dniach oraz 4 miesiącach [25] (ryc. 4).

Przełomem dla leczenia HF były wyniki badania PARADIGM-HF (Prospective comparison of ARNI with ACEI to Determine Impact on Global Mortality and morbidity in Heart Failure trial). Było to wieloośrodkowe, randomizowane badanie kliniczne III fazy, przeprowadzone metodą podwójnie ślepej próby, oceniające długoterminową skuteczność i bezpieczeństwo terapii za pomocą ARNI w porównaniu z enalaprilem w grupie 8442 pacjentów (mediana obserwacji 27 miesięcy) z przewlekłą, objawową HF i LVEF poniżej $40 \%$, poddanych standardowemu, tolerowanemu, zgodnemu z aktualnymi zaleceniami leczeniu HF. Pierwszym lekiem z grupy ARNI jest sakubitryl/walsartan. Jest to molekuła zawierająca inhibitor neprylizyny (sakubitryl) oraz antagonistę receptora dla angiotensyny (walsartan). Sakubitryl poprzez hamowanie neprylizyny, powoduje zwiększenie dostępności przedsionkowego peptydu natriuretycznego (ANP, A-type natriuretic peptide) oraz mózgowego peptydu natriuretycznego (BNP, B-type natriuretic peptide). Efektem 


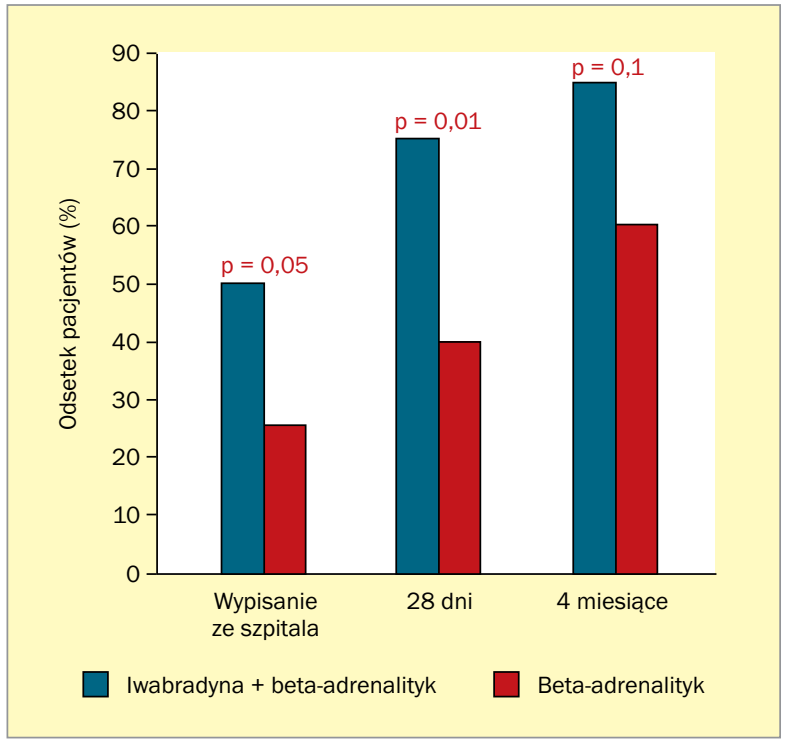

Rycina 4. Odsetek pacjentów z HR $<70$ /min badaniu ETHIC-AHF (na podstawie [25]). HR (heart rate) - rytm serca

klinicznym jest zwiększenie diurezy, wzrost wydalania sodu z moczem, rozkurczenie naczyń oraz hamowanie niekorzystnego remodelingu mięśnia sercowego [26, 27].

Należy oczekiwać, że wyniki badania PARADIGM-HF, które przedstawiono $\mathrm{w}$ tabeli 4 , spowodują ostatecznie, że sakubitryl/walsartan stanie się lekiem zalecanym w pierwszej linii farmakoterapii pacjentów z HF i obniżoną EF $[6,27]$.

Zarówno w fazie wczesnej, jak i późnej okresu największej wrażliwości istotną rolę odgrywa także leczenie chorób współistniejących. W populacji pacjentów po 65. roku życia u 96\% współistnieje przynajmniej jedna dodatkowa
Tabela 4. Wyniki badania PARADIGM-HF (na podstawie [6, 27])

Leczenie sakubitrylem/walsartanem w porównaniu z leczeniem enalaprilem powodowało:

- ograniczenie o 20\% pierwszorzędowego punktu końcowego, na który składały się: zgon z przyczyn sercowo-naczyniowych lub hospitalizacja z powodu HF $(21,8 \%$ v. $26,5 \%$; HR 0,80; 95\% Cl 0,73-0,87; $p<0,001)$;

- redukcję ryzyka zgonu z przyczyn sercowo-naczyniowych o $20 \%$ (13,3\% v. 16,5\%; HR 0,80, 95\% Cl 0,71-0,89; $\mathrm{p}<0,001)$

- redukcję ryzyka hospitalizacji z powodu HF o $21 \%$ (12,8\% v. $15,16 \%$; HR - 0,79, 95\% Cl 0,71-0,89; $p<0,001)$

HF (heart failure) - niewydolność serca; HR (hazard ratio) - współczynnik ryzyka; $\mathrm{Cl}$ (confidence interval) - przedział ufności

choroba, zaś u chorych w przedziale wiekowym 14-66 lat zjawisko to ma miejsce u $74 \%[28,29]$.

Najczęstsze schorzenia towarzyszące HF przedstawia rycina 5.

Wśród pacjentów powyżej 80. roku życia z obniżoną LVEF poniżej $45 \%$ z towarzyszącą chorobą naczyniową i chorobą płuc ryzyko zgonu z przyczyn sercowo-naczyniowych lub ryzyko ponownej hospitalizacji z powodu HF wzrasta 10-24-krotnie [30].

Ze względu na to, że choroby dodatkowe pogarszają przebieg naturalny oraz mogą być przyczyną rozwoju i dekompensacji HF, optymalna terapia HF polega na odpowiednim leczeniu chorób współistniejących, między innymi zapobieganiu niedokrwistości (szczególnie u pacjentów z towarzyszącą przewlekłą chorobą nerek), odpowiedniej kontroli cukrzycy, przewlekłej obturacyjnej choroby płuc oraz nadciśnienia tętniczego. Należy również identyfikować i odpowiednio leczyć pacjentów, którzy mogą odnieść korzyść z rewaskularyzacji [1].

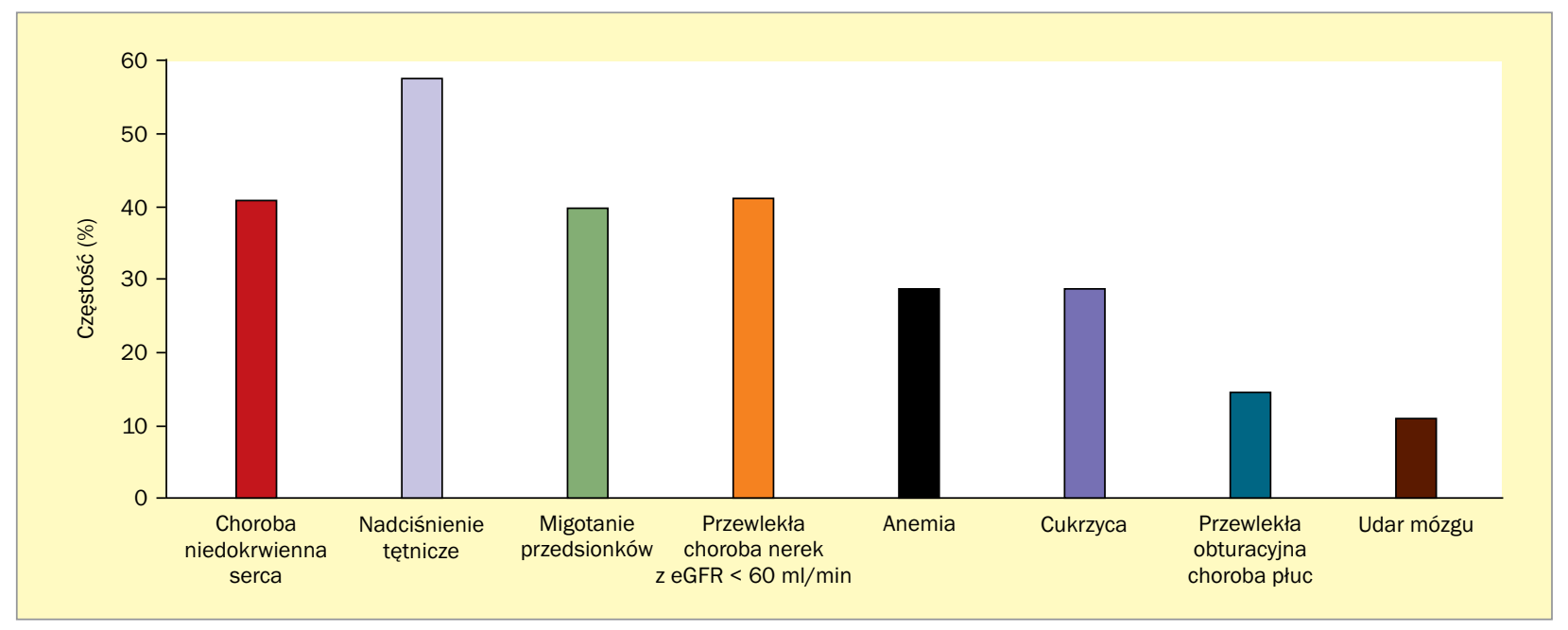

Rycina 5. Częstość występowania chorób współistniejących u pacjentów z niewydolnością serca (na podstawie [29]); *dotyczy napadowego i utrwalonego migotania przedsionków; eGFR (estimated glomerular filtration rate) - współczynnik przesączania kłębuszkowego 


\section{Okres późny}

Faza późna trwa do 6 miesięcy od wypisania ze szpitala. Jednym z najważniejszych celów terapeutycznych tego okresu jest identyfikacja pierwszych objawów klinicznych zaostrzającej się HF, tak aby zapobiec readmisji. W zależności od wartości LVEF, rehospitalizacje związane z HF są poprzedzone wzrostem komorowego ciśnienia napełniania, około 2 tygodni przed wystąpieniem pierwszych objawów klinicznych zaostrzenia HF [31].

Intensywna obserwacja w kierunku pojawienia się symptomów wskazujących na rozpoczynający się zastój (w tym zastosowanie biomarkerów) i odpowiednia optymalizacja leczenia farmakologicznego są kluczowe dla zapobiegania ponownym hospitalizacjom, a tym samym dla rokowania pacjenta z HF. Po 6 miesiącach fazy późnej ryzyko ponownych hospitalizacji spada i osiaga plateau, które może trwać nawet do kilku miesięcy.

\section{Opieka nad pacjentem z niewydolnością serca w fazie największej wrażliwości - oczekiwania a rzeczywistość}

Według wytycznych ESC pierwsza wizyta u lekarza POZ powinna odbyć się w ciągu pierwszego tygodnia od dnia wypisu ze szpitala po hospitalizacji z powodu zaostrzenia HF, zaś kontakt z kardiologiem w ciągu 2 tygodni, jeśli to możliwe [1]. W wytycznych American College of Cardiology Foundation/American Heart Association (ACCF/AHA) zakłada się kontakt telefoniczny z lekarzem w ciągu 3 dni od wypisania oraz wizytę lekarską w ciągu 14 dni [19]. W Polsce nie istnieje system opieki ambulatoryjnej nad pacjentem z niewydolnością serca i z tego powodu chory po hospitalizacji trafia zbyt późno do lekarza rodzinnego, a jeszcze później do kardiologa. Według rejestru FUTURE, sporządzonego w 2012 roku, jedynie 28\% pacjentów w ciągu 3 miesięcy ma wyznaczony termin wizyty w poradni kardiologicznej [32]. Zważywszy na fakt, że najwięcej ponownych hospitalizacji ma miejsce w tym właśnie okresie, system opieki ambulatoryjnej wymaga wprowadzenia zmian. Metra i wsp. [33] dowiedli, że śmiertelność 30-dniowa po hospitalizacji w istotnym stopniu zależy od opieki poszpitalnej (ryc. 6).

Koniecznym warunkiem poprawy jakości opieki nad pacjentem z HF jest stworzenie multidyscyplinarnych zespołów terapeutycznych składających się między innymi z lekarza, pielęgniarki, dietetyka, psychologa i rehabilitanta. Zadania poszczególnych członków zespołu zostały przedstawione w tabeli 5. Spójny system opieki nad pacjentem z HF łączący elementy opieki ambulatoryjnej z opieką szpitalną skutkuje zmniejszeniem liczby hospitalizacji z powodu HF i śmiertelności wśród osób wypisywanych ze szpitala [34, 35]. Do jednego z głównych zadań zespołu HF należy długoterminowa obserwacja, a także identyfikacja pacjenta wysokiego ryzyka.

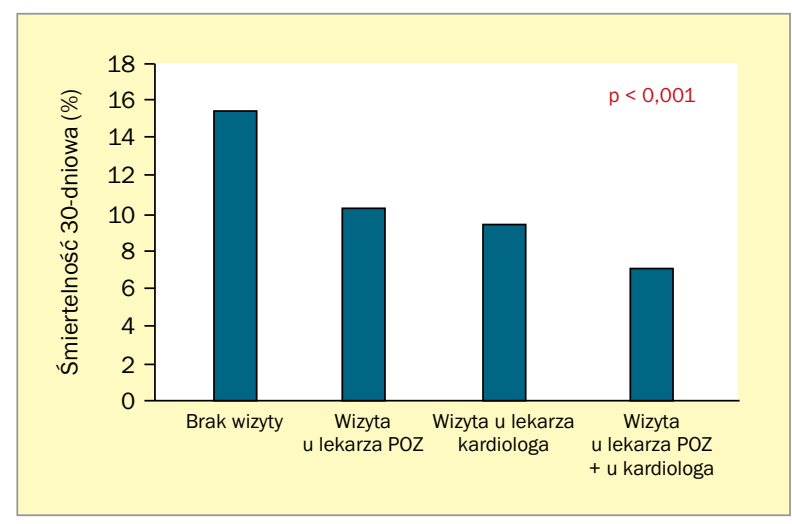

Rycina 6. Śmiertelność 30-dniowa w zależności od opieki ambulatoryjnej (na podstawie [33]); POZ - podstawowa opieka zdrowotna

Tabela 5. Skład i zadania członków zespołu niewydolności serca (HF, heart failure)

\section{Wielospecjalistyczny zespół zajmujący się leczeniem HF}

Lekarz

Badanie podmiotowe i przedmiotowe

Wstępna diagnostyka, postawienie rozpoznania

Skierowanie do ośrodka specjalistycznego

- poradnia kardiologiczna w celu wykonania badania echokardiograficznego

Długotrwała opieka po ustaleniu rozpoznania i ustalenie dalszego postępowania

Pielęgniarka Edukacja pacjenta - etiologia, objawy niewydolności serca, rokowanie, restrykcja płynów i sodu, aktywność fizyczna, aktywność seksualna, konieczność szczepień dodatkowych, kontrola masy ciała, ciśnienia tętniczego, częstości rytmu serca, udostępnianie materiałów edukacyjnych

Weryfikacja wiedzy pacjenta na temat swojej choroby

Ustalanie terminów wizyt lekarskich

Koordynacja procesu leczniczego - pośredniczenie w kontaktach między lekarzem $\mathrm{POZ}$ a specjalistą kardiologiem

Ustalanie konieczności konsultacji dodatkowych - z psychologiem, dietetykiem, rehabilitantem

Dietetyk Edukacja i ustalenie odpowiedniej diety

Rehabilitant Wykonywanie testu 6-minutowego marszu

Edukacja w zakresie ćwiczeń, niezbędnej aktywności fizycznej

Psycholog Monitorowanie stanu psychicznego w celu uniknięcia bagatelizowania choroby i opóźnienia leczenia

Pomoc w akceptacji choroby

Włączenie rodziny do procesu terapeutycznego

Wykonywanie testów oceniających jakość życia

POZ - podstawowa opieka zdrowotna 


\section{Podsumowanie}

Jakość opieki w fazie największej wrażliwości ma decydujące znaczenie dla rokowania pacjenta z HF. Aby uniknąć ponownych hospitalizacji, a tym samym poprawić rokowanie w tej grupie chorych, należy wypisywać pacjentów po osiągnięciu euwolemii i stabilizacji hemodynamicznej, po zaplanowaniu długoterminowego nadzoru po wypisie. Koordynacja wielospecjalistycznej opieki w tym okresie umożliwia osiągnięcie stanu stabilizacji klinicznej nawet do 12 miesięcy. Integracja wielospecjalistycznych działań, takich jak edukacja chorych, optymalizacja farmakoterapii, wsparcie psychospołeczne i poprawa dostępności do systemu ochrony zdrowia, to warunek konieczny do zmniejszenia śmiertelności wśród pacjentów z HF.

\section{Konflikt interesów}

Autorki brały udział w badaniu TRANSITION.

\section{Abstract}

Heart failure is still a serious clinical problem. Each subsequent hospitalization due to acute heart failure worsens prognosis and increases risk of death in patients with heart failure. Prevention of re-hospitalizations is one of the main therapeutic goals of heart failure treatment. The most important prognostic period for patient with acute heart failure and decompensation of chronic heart failure is called vulnerable phase. This is a time from acute symptoms of disease to six months after discharge from hospital. Vulnerable phase contains three periods: very early phase, early phase and late phase. Identification of therapeutic goals in each of these phases is pivotal for long-term clinical stabilization. Optimal pharmacological treatment and complex, multidisciplinary care on each of these phases results in reduction of re-hospitalizations and improvement of prognosis patients with heart failure.

Key words: heart failure, vulnerable phase

Folia Cardiologica 2018; 13, 1: 71-78

\section{Piśmiennictwo}

1. Ponikowski P, Voors AA, Anker SD, et al. Authors/Task Force Members, Document Reviewers. 2016 ESC Guidelines for the diagnosis and treatment of acute and chronic heart failure: The Task Force for the diagnosis and treatment of acute and chronic heart failure of the European Society of Cardiology (ESC). Developed with the special contribution of the Heart Failure Association (HFA) of the ESC. Eur J Heart Fail. 2016; 18(8): 891-975, doi: 10.1002/ejhf.592, indexed in Pubmed: 27207191.

2. Rywik TM, Kołodziej P, Targoński R, et al. Characteristics of the heart failure population in Poland: ZOPAN, a multicentre national programme. Kardiol Pol. 2011; 69(1): 24-31, indexed in Pubmed: 21267960.

3. Rywik TM, Zieliński T, Piotrowski W, et al. Heart failure patients from hospital settings in Poland: population characteristics and treatment patterns, a multicenter retrospective study. Cardiol J. 2008; 15(2): 169-180, indexed in Pubmed: 18651402.

4. Fang J, Mensah GA, Croft JB, et al. Heart failure-related hospitalization in the U.S., 1979 to 2004. J Am Coll Cardiol. 2008; 52(6): 428-434, doi: 10.1016/j.jacc.2008.03.061, indexed in Pubmed: 18672162.

5. Czech M, Opolski G, Zdrojewski T, et al. Koszty HF w Polsce z punktu widzenia płatnika. Program oceny diagnostyki, leczenia i kosztów u chorych z HF w losowo wybranych jednostkach lecznictwa otwartego i zamkniętego na poziomie podstawowym, wojewódzkim i specjalalistycznym: POLKARD. Kardiol Pol. 2013; 71(3): 224-232, doi: 10.5603/kp.2013.0032, indexed in Pubmed: 23575775.

6. Lelonek M. Niewydolność serca i powtarzające się hospitalizacje. Folia Cardiol. 2016; 11(1): 37-46, doi: 10.5603/fc.2016.0005.
7. Lloyd-Jones D, Adams RJ, Brown TM, et al. American Heart Association Statistics Committee and Stroke Statistics Subcommittee, Writing Group Members. Heart disease and stroke statistics - 2010 update: a report from the American Heart Association. Circulation. 2010; 121(7): e46-e215, doi: 10.1161/CIRCULATIONAHA.109.192667, indexed in Pubmed: 20019324.

8. Cook TD, Greene SJ, Kalogeropoulos AP, et al. Temporal Changes in Postdischarge Mortality Risk After Hospitalization for Heart Failure (from the EVEREST Trial). Am J Cardiol. 2016; 117(4): 611-616, doi: 10.1016/j.amjcard.2015.11.050, indexed in Pubmed: 26742474.

9. Solomon SD, Dobson J, Pocock S, et al. Candesartan in Heart failure: Assessment of Reduction in Mortality and morbidity (CHARM) Investigators. Influence of nonfatal hospitalization for heart failure on subsequent mortality in patients with chronic heart failure. Circulation. 2007; 116(13): 1482-1487, doi: 10.1161/CIRCULATIONAHA.107.696906, indexed in Pubmed: 17724259.

10. Setoguchi S, Stevenson LW, Schneeweiss S. Repeated hospitalizations predict mortality in the community population with heart failure. Am Heart J. 2007; 154(2): 260-266, doi: 10.1016/j.ahj.2007.01.041, indexed in Pubmed: 17643574.

11. Desai AS. The three-phase terrain of heart failure readmissions. Circ Heart Fail. 2012; 5(4): 398-400, doi: 10.1161/CIRCHEARTFAILURE.112.968735, indexed in Pubmed: 22811548.

12. Gheorghiade M, Pang PS, Ambrosy AP, et al. A comprehensive, longitudinal description of the in-hospital and post-discharge clinical, laboratory, and neurohormonal course of patients with heart failure who die or are re-hospitalized within 90 days: analysis from the EVEREST 
trial. Heart Fail Rev. 2012; 17(3): 485-509, doi: 10.1007/s10741011-9280-0, indexed in Pubmed: 21932146.

13. Yilmaz MB, Mebazaa A. Definition and characteristics of the vulnerable phase in heart failure. Medicographia. 2015; 37(2): 139-143.

14. Ponikowski $P$, Jankowska $E$. Treatment optimization in heart failure patients from admission to discharge. Medicographia. 2015; 37(2): 149-154.

15. Teerlink JR, Cotter G, Davison BA, et al. RELAXin in Acute Heart Failure (RELAX-AHF) Investigators. Serelaxin, recombinant human relaxin-2, for treatment of acute heart failure (RELAX-AHF): a randomised, placebo-controlled trial. Lancet. 2013; 381(9860): 29-39, doi: 10.1016/ /S0140-6736(12)61855-8, indexed in Pubmed: 23141816.

16. Butler J, Braunwald E, Gheorghiade M. Recognizing worsening chronic heart failure as an entity and an end point in clinical trials. JAMA. 2014; 312(8): 789-790, doi: 10.1001/jama.2014.6643, indexed in Pubmed: 25157719.

17. Harjola VP, Mullens W, Banaszewski M, et al. Organ dysfunction, injury and failure in acute heart failure: from pathophysiology to diagnosis and management. A review on behalf of the Acute Heart Failure Committee of the Heart Failure Association (HFA) of the European Society of Cardiology (ESC). Eur J Heart Fail. 2017; 19(7): 821-836, doi: 10.1002/ejhf.872, indexed in Pubmed: 28560717.

18. Nikolaou M, Parissis J, Yilmaz MB, et al. Liver function abnormalities, clinical profile, and outcome in acute decompensated heart failure. Eur Heart J. 2013; 34(10): 742-749, doi: 10.1093/eurhearti/ehs332, indexed in Pubmed: 23091203.

19. Yancy C, Jessup M, Bozkurt B, et al. 2013 ACCF/AHA Guideline for the Management of Heart Failure. J Am Coll Cardiol. 2013; 62(16): e147-e239, doi: 10.1016/j.jacc.2013.05.019.

20. Bohm M. Changes in predicting heart failure readmission: focus on heart rate. Medicographia. 2015; 37(2): 197-201.

21. Fonarow G, Abraham W, Albert N, et al. Dosing of Beta-Blocker Therapy Before, During, and After Hospitalization for Heart Failure (from Organized Program to Initiate Lifesaving Treatment in Hospitalized Patients With Heart Failure). Am J Cardiol. 2008; 102(11): 1524-1529, doi: 10.1016/j.amjcard.2008.07.045, indexed in Pubmed: 19026308.

22. DeVore AD, Mi X, Mentz RJ, et al. Discharge heart rate and $\beta$-blocker dose in patients hospitalized with heart failure: Findings from the $\mathrm{OP}$ TIMIZE-HF registry. Am Heart J. 2016; 173: 172-178, doi: 10.1016/j. ahj.2015.10.026, indexed in Pubmed: 26920611.

23. Swedberg K, Komajda M, Böhm M, et al. SHIFT Investigators. Ivabradine and outcomes in chronic heart failure (SHIFT): a randomised placebo-controlled study. Lancet. 2010; 376(9744): 875-885, doi: 10.1016/S0140-6736(10)61198-1, indexed in Pubmed: 20801500.

24. Hidalgo FJ, Anguita M, Castillo JC, et al. Effect of early treatment with ivabradine combined with beta-blockers versus beta-blockers alone in patients hospitalised with heart failure and reduced left ventricular ejection fraction (ETHIC-AHF): A randomised study. Int J Cardiol. 2016; 217: 7-11, doi: 10.1016/j.ijcard.2016.04.136, indexed in Pubmed: 27167103.

25. McMurray JJV, Packer M, Desai AS, et al. PARADIGM-HF Investigators and Committees. Angiotensin-neprilysin inhibition versus enalapril in heart failure. N Engl J Med. 2014; 371(11): 993-1004, doi: 10.1056/ /NEJMoa1409077, indexed in Pubmed: 25176015.

26. Sobczak S, Lelonek M. LCZ696 przełomem w leczeniu przewlekłej niewydolności serca z obniżoną frakcją wyrzutową lewej komory. Folia Cardiol. 2016; 10(6): 403-409, doi: 10.5603/fc.2015.0077.

27. Braunstein J, Anderson G, Gerstenblith G, et al. Noncardiac comorbidity increases preventable hospitalizations and mortality among medicare beneficiaries with chronic heart failure. Journal of the American College of Cardiology. 2003; 42(7): 1226-1233, doi: 10.1016/ /s0735-1097(03)00947-1.

28. van Deursen VM, Urso R, Laroche C, et al. Co-morbidities in patients with heart failure: an analysis of the European Heart Failure Pilot Survey. Eur J Heart Fail. 2014; 16(1): 103-111, doi: 10.1002/ejhf.30, indexed in Pubmed: 24453099.

29. Cichocka-Radwan A, Lelonek M. Czynniki prognostyczne w obserwacji rocznej w przewlekłej niewydolności serca u chorych po 80. roku życia. Kardiol Pol. 2017; 75(2): 164-173, doi: 10.5603/kp.a2016.0132, indexed in Pubmed: 27714717.

30. Zile MR, Bennett TD, St John Sutton M, et al. Transition from chronic compensated to acute decompensated heart failure: pathophysiological insights obtained from continuous monitoring of intracardiac pressures. Circulation. 2008; 118(14): 1433-1441, doi: 10.1161/ /CIRCULATIONAHA.108.783910, indexed in Pubmed: 18794390.

31. Cohen Solal A, Leurs I, Assyag P, et al. French National College of Cardiologists. Optimization of heart FailUre medical Treatment after hospital discharge according to left ventricUlaR Ejection fraction: the FUTURE survey. Arch Cardiovasc Dis. 2012; 105(6-7): 355-365, doi: 10.1016/j.acvd.2012.04.003, indexed in Pubmed: 22800720.

32. Metra M, Gheorghiade M, Bonow RO, et al. Postdischarge assessment after a heart failure hospitalization: the next step forward. Circulation. 2010; 122(18): 1782-1785, doi: 10.1161/CIRCULATIONAHA.110.982207, indexed in Pubmed: 20956215.

33. McAlister FA, Stewart S, Ferrua S, et al. Multidisciplinary strategies for the management of heart failure patients at high risk for admission: a systematic review of randomized trials. J Am Coll Cardiol. 2004; 44(4): 810-819, doi: 10.1016/j.jacc.2004.05.055, indexed in Pubmed: 15312864

34. Feltner C, Jones CD, Cené CW, et al. Transitional care interventions to prevent readmissions for persons with heart failure: a systematic review and meta-analysis. Ann Intern Med. 2014; 160(11): 774-784, doi: 10.7326/M14-0083, indexed in Pubmed: 24862840. 